(C) 2020. This manuscript version is made available under the CC-BY-NC-ND

4.0 license http://creativecommons.org/licenses/by-nc-nd/4.0/

\title{
Incretin-based therapies and renin-angiotensin system: looking for new therapeutic potentials in the diabetic milieu
}

Running Title: Incretin based therapies and renin-angiotensin system

Habib Yaribeygi ${ }^{1^{*}}$, Mina Maleki ${ }^{2}$, Thozhukat Sathyapalan ${ }^{3}$, Tannaz Jamialahmadi ${ }^{4,5,6}$, Amirhossein Sahebkar ${ }^{7,8,9^{*}}$

${ }^{1}$ Research Center of Physiology, Semnan University of Medical Sciences, Semnan, Iran

${ }^{2}$ Chronic Kidney Disease Research Center, Shahid Beheshti University of Medical Sciences, Tehran, Iran

${ }^{3}$ Academic Diabetes, Endocrinology and Metabolism, Hull York Medical School,

University of Hull

${ }^{4}$ Biotechnology Research Center, Pharmaceutical Technology Institute, Mashhad University of Medical Sciences, Mashhad, Iran

${ }^{5}$ Department of Food Science and Technology, Quchan Branch, Islamic Azad University, Quchan, Iran

${ }^{6}$ Department of Nutrition, Faculty of Medicine, Mashhad University of Medical Sciences, Mashhad, Iran

${ }^{7}$ Halal Research Center of IRI, FDA, Tehran, Iran

${ }^{8}$ Biotechnology Research Center, Pharmaceutical Technology Institute, Mashhad University of Medical Sciences, Mashhad, Iran

${ }^{9}$ Neurogenic Inflammation Research Center, Mashhad University of Medical Sciences, Mashhad

\section{*Corresponding Author}

Amirhossein Sahebkar, Biotechnology Research Center, Pharmaceutical Technology Institute, Mashhad University of Medical Sciences, Mashhad 9177948564, Iran. Tel: +985138002299; Fax: +985138002287; E-mail: sahebkara@mums.ac.ir; amir_saheb2000@yahoo.com 
Habib Yaribeygi, Research Center of Physiology, Semnan University of Medical Sciences, Semnan, Iran, Tel: +989355644190

Running Title: Anti-diabetic mechanisms of imeglimin

\begin{abstract}
Incretin-based therapies include pharmacologic agents such as glucagon like peptide-1 receptor agonists and dipeptidyl peptidase-4 inhibitors which exert potent anti-hyperglycemic effects in the diabetic milieu. They are also shown to have extra-pancreatic effects. Renin-angiotensin system is part of the endocrine system which is widely distributed in the body and is closely involved in water and electrolyte homeostasis as well as renal and cardiovascular functions. Hence the renin-angiotensin system is the main target for treating patients with various renal and cardiovascular disorders. There is growing evidence that incretins have modulatory effects on renin-angiotensin system activity; thereby, can be promising therapeutic agents for the management of renal and cardiovascular disorders. But the exact molecular interactions between incretins and renin-angiotensin system are not clearly understood. In this current study, we have reviewed the possible molecular mechanisms by which incretins modulate renin-angiotensin system activity.
\end{abstract}

Keywords: incretin, glucagon like peptide-1 receptor agonists, dipeptidyl peptdase-4 inhibitors, renin-angiotensin system, $\mathrm{Na}+/ \mathrm{H}+$ exchanger isotope 3 . 


\section{Introduction}

Renin-angiotensin system (RAS) is a key player in salt and fluid homeostasis in the body and so is closely associated with renal and cardiovascular physiology (Schmieder et al. , 2007). RAS closely regulates hemodynamic states and promptly react to any changes in osmotic pressure and blood volume (Schmieder et al., 2007). RAS is a key component in regulating steady-state of hemodynamic status by modulating water and electrolyte balance (Schmieder et al., 2007). Any defect in RAS will lead to the development of cardiovascular and renal pathologies (Fyhrquist and Saijonmaa, 2008, Schmieder et al., 2007). Hence modulating the activity of RAS is the main target for normalizing renal and cardiovascular functions in various conditions including diabetes (Fyhrquist and Saijonmaa, 2008). Therefore, antidiabetic agents which can modulate RAS activity could provide further therapeutic effects more than reducing hyperglycemia (Kong et al. , 2014).

Incretin-based therapies are commonly used in patients with type 2 diabetes to lower blood and is developed based on the hypoglycemic effects of incretin hormones (Lovshin and Drucker, 2009). Incretins are a group of intestinal peptides which reduces postprandial glucose by several mechanisms (Koliaki and Doupis, 2011, Lovshin and Drucker, 2009). Two main class of antidiabetic drugs are available based on incretin physiology (Lovshin and Drucker, 2009). These agents have potent hypoglycemic effects (Lovshin and Drucker, 2009, Ussher and Drucker, 2014). However, there is growing evidence on the extrapancreatic effects of these drugs including renoprotective effects (Koliaki and Doupis, 2011, Lovshin and Zinman, 2014, Tonneijck et al. , 2014). This could potentially provide further beneficial effects, such as lowering blood pressure and improving renal function (Baretić et al. , 2018). In the current study, we reviewed the potential RAS modulatory effects of incretin-based medications with a focus on promising renoprotective potentials. 
Incretin based therapies are used mainly in type 2 diabetes which is the most common type of diabetes and is associated with insulin resistance in the peripheral tissue (Association, 2014). The other main forms of diabetes are type 1 diabetes, gestational diabetes, maturity-onset diabetes of the young, latent autoimmune diabetes of the adults and secondary diabetes due to pancreatitis and medications such as steroids (Association, 2014, de Faria Maraschin, 2013, O’Neal et al. , 2016).

\section{Renin-Angiotensin System; roles in renal disorders}

Renin-angiotensin system (RAS) or renin-angiotensin-aldosterone system (RAAS) is a crucial hormonal system responsible for water and electrolytes homeostasis as well as systemic vascular resistance (Boulpaep et al. , 2009). This system is triggered by releasing the renin from the kidneys, mainly in response to hypovolemia or hyponatremia (Boulpaep et al., 2009). Renin is synthesized from its precursor prorenin and stored in the renal juxtaglomerular cells (Fountain and Lappin, 2019). Renin then cleaves angiotensinogen (produced by the liver) into angiotensin I (AngI), which is subsequently converted to angiotensin II (AngII) by the angiotensin-converting enzyme (ACE) predominantly on the surface of vascular endothelial cells of the lungs as well as proximal renal tubules (Fountain and Lappin, 2019). Ang II is a potent vasoconstrictive peptide that increases peripheral vascular resistance and blood pressure (Fountain and Lappin, 2019). This system is highly sensitive to any changes in plasma concentration, blood pressure and blood volume, and reacts to these changes promptly (Khanna et al. , 2017). Ang II primarily acts as a very strong vasoconstrictor (Khanna et al., 2017). This hormone acts by binding with type 1 (AT1) and type 2 (AT2) receptors (Okuyama et al. , 1999). Also, it stimulates the release of aldosterone 
from the adrenal gland (zona glomerulosa) which regulates the homeostasis of mainly sodium and potassium in the body (McCormick and Bradshaw, 2006).

RAAS has an important role in renal function by regulating fluid and electrolyte homeostasis (Fountain and Lappin, 2019). Since the kidney has all elements involved in the RAS (or RAAS), it has its specific system known as "intrarenal RAS" (Siragy and Carey, 2010). Intrarenal RAAS not only regulates glomerular hemodynamics and tubular sodium transport but also activates a number of inflammatory, oxidative and fibrotic processes involved in the development of diabetic and non-diabetic nephropathies (Siragy and Carey, 2010). It has been well confirmed that abnormal RAS activity is involved in the development of various renal disorders (Balamuthusamy et al. , 2008, Molitch et al. , 2015, Nangaku and Fujita, 2008). Both Ang II and aldosterone can initiate and worsen various pathophysiologic pathways such as inflammation, oxidative stress, apoptosis and fibrosis (Siragy and Carey, 2010, Urushihara and Kagami, 2017). It has been demonstrated that RAAS inhibitors can reduce albuminuria and improve renal efficiency (Parving et al. , 2012). Activation of intrarenal RAAS is the main feature of diabetic kidney diseases (Thomas, 2017). Also, patients with diabetic renal failure usually have higher activities of mineralocorticoid receptors that are probably driven by increased levels of circulating aldosterone due to higher RAAS activity (Messaoudi et al. , 2012). Therefore, many pharmacological agents targeting this system were developed for improving renal function through modulating RAAS activities (Fountain and Lappin, 2019). Inhibitors of ACE, agents blocking Ang II receptors and direct renin inhibitors are three known classes of medications targeting RAS activities that are widely used in patients with renal and cardiovascular diseases (Fountain and Lappin, 2019).

\section{Incretin-based antidiabetic medications}

Incretins are a group of intestinal metabolic hormones such as glucagon like peptide-1 (GLP-1) and gastric inhibitory peptide (GIP), which decline postprandial glycaemia through 
several metabolic pathways such as inhibition of glucagon release, stimulation of insulin secretion, delaying gastric emptying, suppression of appetite, diminishing intestinal absorption of nutrients, improving lipid metabolism and promoting functions of pancreatic $\beta$-cells (Baggio and Drucker, 2007, Ding et al. , 2006, Drucker and Nauck, 2006, Meier, 2012, Scott and Moran, 2007). The two main classes of antidiabetic agents developed based on incretin physiology are GLP-1 receptor agonists (GLP-1RA) and dipeptidyl peptidase-4 inhibitors (DPP-4i) (Table 1) (Drucker and Nauck, 2006, Islam, 2016).

GLP-1RA is a group of medications used in the management of type 2 diabetes that provide glucose-lowering effects by stimulation of GLP-1 receptors and thereby mimicking the hypoglycemic effects of incretin hormones (Drucker and Nauck, 2006, Islam, 2016). These medications bind to GLP-1 receptors on the surface of pancreatic $\beta$-cells. This GLP-1 receptor is a member of G-protein coupled receptors and its activation followed by generation of cyclic adenosine monophosphate (cAMP) and cellular depolarization leads to insulin secretion (Baggio and Drucker, 2007, Wootten et al. , 2011). GLP-1 is naturally metabolized by a protease known as dipeptidyl peptidase-4 (DPP-4) (Association, 2018). This enzyme is primarily a serine exopeptidase peptide cleaving X-proline or X-alanine dipeptides from the N-terminus of targeted polypeptides including GLP-1 thereby deactivating them (Baetta and Corsini, 2011). Inhibition of DPP-4 activity results in more physiologic effects of its substrates including GLP-1 (Baetta and Corsini, 2011). Therefore, DPP-4 inhibitors (DPP4-i) can reduce blood glucose by increasing the active circulatory levels of GLP-1 (Ahren, 2007, Association, 2018). GLP-1RA and DPP-4i have some differences such as the effect on body weight, degree of improvement in glycemic control and their adverse effect profile (Association, 2018). 


\begin{tabular}{|c|c|c|c|}
\hline & Approved Forms & Mechanisms of Action & Ref. \\
\hline $\begin{array}{c}\text { GLP-1R } \\
\text { A }\end{array}$ & $\begin{array}{c}\text { Exenatide (Exendin-4), } \\
\text { Albiglutide, Liraglutide, } \\
\text { Lixisenatide, Semaglutide, } \\
\text { Dulaglutide }\end{array}$ & $\begin{array}{l}\text { Potentiate glucose-lowering } \\
\text { effects of incretins }\end{array}$ & $\begin{array}{l}\text { (Drucker } \\
\text { and Nauck, } \\
\text { 2006, Islam, } \\
\text { 2016) }\end{array}$ \\
\hline DPP-4i & $\begin{array}{l}\text { Sitagliptin, Saxagliptin, } \\
\text { Vildagliptin, Linagliptin }\end{array}$ & $\begin{array}{l}\text { Increase the active } \\
\text { circulatory levels of } \\
\text { incretins }\end{array}$ & $\begin{array}{l}\text { (Ahren, } \\
2007, \\
\text { Association, } \\
\text { 2018) }\end{array}$ \\
\hline
\end{tabular}

Table 1: incretin-based antidiabetic drugs

\section{Incretin-based therapies and Renin-Angiotensin System}

Incretin-based therapies are effective in improving glycemia in patients with type 2 diabetes (Drucker and Nauck, 2006, Islam, 2016). However, they also have some extrapancreatic effects such as RAAS modulation and renoprotective effects (Muskiet et al. , 2014, Pyke et al. , 2014). There is growing evidence that GLP-1 interacts with RAAS activities, decline Na reabsorption in the proximal tubule and can modulate renal hemodynamics (Skov et al. , 2013). These observations suggest that incretins-based therapies and RAS blockades have synergistic effects in combination and so, not recommended to use together (Molitch et al., 2015). In the following sections, we discuss the possible interactions between incretin-based therapies and RAAS, which may provide promising renoprotective effects, especially in the diabetic milieu.

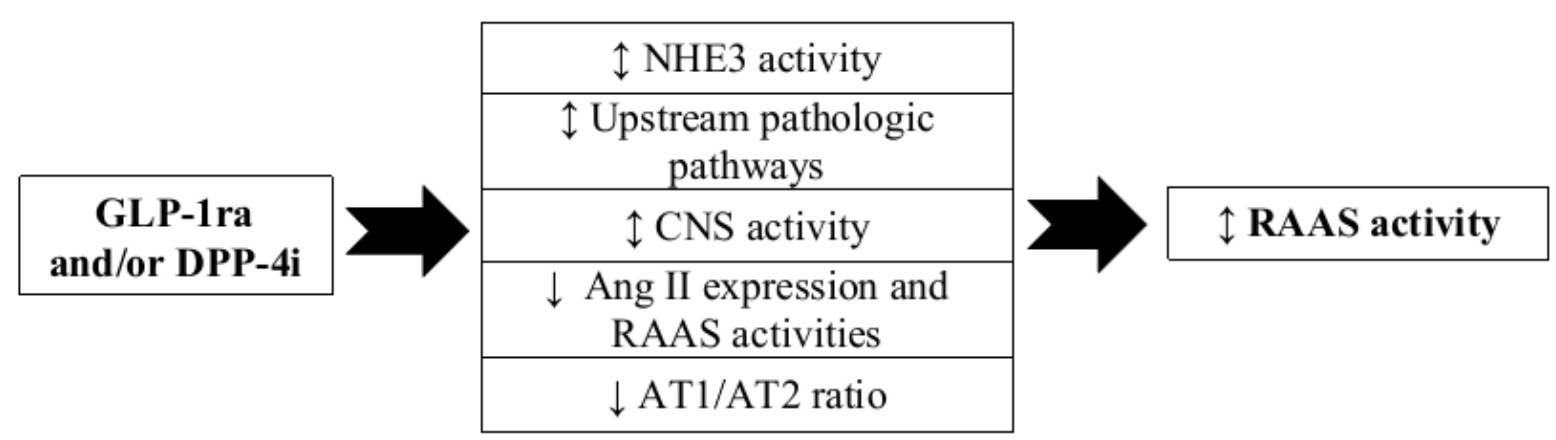


Fig 1; Molecular mechanisms by which incretins modulate RAAS activity (RAAS= renin-angiotensin-aldosterone system, $\mathrm{CNS}=$ central nervous system, $\mathrm{AT}=$ angiotensin receptor)

\section{Direct Ang II inhibition}

GLP based therapies can attenuate RAAS activity by decreasing Ang II expression and activity (Baretić et al., 2018, Beraldo et al. , 2019, Kawase et al. , 2016). Beraldo et al. in 2019 found that 8 week treatment with sitagliptin down-regulated Ang II while increased Ang 1-7 in cardiac tissues of nephrectomized rats (Beraldo et al., 2019). Koibuchi et al. in 2014 found that linagliptin (DPP-4i) down-regulated Ang II in cardiac tissues (Koibuchi et al. , 2014). Also, Mima et al. in 2012 provided evidence showing that GLP-1 receptor signaling attenuated Ang II signaling by a PKC dependent mechanism in glomerular endothelial cells of diabetic mice overexpressing PKC (Mima et al. , 2012). Moreover, Baretic et al. in 2018 conducted a clinical study demonstrating GLP-1 infusion suppressed Ang II circulating level in healthy participants (Baretić et al., 2018). The key finding of these studies was that GLP-1 interfere with Ang II secretion. But the exact molecular interactions are not fully understood. Current knowledge suggests that GLP-1 can inhibit Ang II actions via PKA $^{1}$ dependent phosphorylation, direct effects of GLP-1 on renal juxtaglomerular cells, damping the tubuloglomerular feedback by inhibition of proximal sodium transport and direct Ang II down-regulation (Baretić et al., 2018, Koibuchi et al., 2014, Mima et al., 2012, Sedman et al. , 2017). However, more studies are still required to confirm these effects.

\section{Modulation of $\mathrm{Na}+/ \mathrm{H}+$ exchanger isotope 3 Activity}

$\mathrm{Na}+/ \mathrm{H}+$ exchanger isotope 3 (NHE3) is a protein located in the brush border and apical membrane of intestinal cells as well as proximal renal tubules (Tamura et al. , 2018, Yip and Tse, 2014). This protein is mainly responsible for sodium and water balance and acid-base

\footnotetext{
${ }^{1}$ Protein kinase $\mathrm{A}$
} 
homeostasis via exchanging sodium with hydrogen ions and regulating the osmotic pressure and diuresis (Tamura et al., 2018, Yip and Tse, 2014). Experimental evidence demonstrates that NHE3 activity is involved in the effects of Ang II via AT1 receptor activation (Du Cheyron et al. , 2003, Riquier-Brison et al. , 2010, Tamura et al., 2018). It has been shown that Ang II induces NHE3 activity via promoting its localization on the cellular membrane (Du Cheyron et al., 2003).

There is growing evidence that GLP-1 inhibits NHE3 protein and its activities (Crajoinas et al. , 2016, Du Cheyron et al., 2003, Skov, 2014). They found that GLP-1 receptor induction via either GLP-1RA and DPP-4i inhibits NHE3 trafficking and reduce its downstream effects (Crajoinas et al., 2016, Girardi et al. , 2008). There is also some evidence that GLP-1 could directly downregulate NHE3 protein (Crajoinas et al. , 2011). This suggests the GLP-1 has a role in hypertensive disorders and sodium retention (Crajoinas et al., 2011). While the effects of Ang II is dependent on NHE3 activity, these inhibitory effects of GLP-1 on NHE3 may be the other possible link by which GLP-1 modulates Ang II activities (Carraro-Lacroix et al. , 2009, Crajoinas et al., 2016, Kim et al. , 2013, Skov, 2014, Skov et al., 2013). Therefore, the natriuretic effects of Ang II is under the influence of GLP-1, which can modulate NHE3 activity (Carraro-Lacroix et al., 2009, Girardi et al. , 2004, Kim et al., 2013). However, the exact mechanism by which GLP-1 modulate NHE3 activities is not well understood.

\section{Modulation of upstream RAAS-induced pathophysiology}

RAAS activity is under the influence of various pathophysiologic pathways such as oxidative stress and inflammation (Husain et al. , 2015, Touyz, 2004, Virdis et al. , 2011). It has been shown that oxidative stress and inflammation promote RAAS activation in several ways and thereby induce its downstream effects (Husain et al., 2015, VAZIRI, 2008). Therefore, one can hypothesize that modulation of these deleterious pathways could modulate RAAS activation indirectly. There is evidence implying that GLP-1 exerts antioxidant and 
anti-inflammatory effects (Alam et al. , 2015, Li et al. , 2016, Yaribeygi et al. , 2020). These effects of GLP-1 based therapies could be another link between these agents and RAAS activation (Skov, 2014) which needs further evaluation.

\section{Modulation of CNS-Induced RAAS Activation}

The central nervous system (CNS) has a regulatory role in RAAS activity (Choi et al. , 2011, Tsuda, 2012, Von Bohlen und Halbach and Albrecht, 2006). It has been well confirmed that the CNS has its own RAS with all its related components and receptors such as AT1 and AT2 (Choi et al., 2011). This system is expressed in most area of CNS and produce bioactive compounds such as Ang 1-7, Ang II, Ang IV and Ang 1-8 (Nakagawa et al. , 2020). CNS dependent RAAS is involved not only in the hemodynamic processes and regulation of BP, but also in many biological and neurobiological activities as processing sensory information, learning, memory, and emotional responses (Nakagawa et al., 2020).

There is some evidence suggesting that incretins have modulatory effects of CNS-dependent RAAS activities, although this complex relationship has not fully understood yet (Zhang et al. , 2019). Beside GLP-1, DPP-4i cleaves several biologic peptides such as substance P, which are released from the ends of primary afferent sensory nerve fibers producing vasodilatory and sympathomimetic effects (Tonneijck et al., 2014, Wilson et al. , 2019). It is also responsible for cleaving neuropeptide Y (NPY) which is a metabolic neurotransmitter in the sympathetic nervous system (Tonneijck et al., 2014). Both of these two peptides (substance P and NPY) have modulatory effects on RAAS activity and when incretins-based therapies are combined with ACE inhibitors, these effects will be exaggerated (Devin et al. , 2014, Molitch et al., 2015, Tonneijck et al., 2014). Therefore, DPP-4i has been suggested as having antihypertensive potential by negatively modulating the RAAS activities (Zhang et al., 2019). Stromal-cell-derived factor-1 (SDF-1) and natriuretic peptide B (BNP) are other main substrates of DPP-4i which have modulatory effects of CNS as well as RAAS (Zhang et 
al., 2019). However, some studies revealed that high doses of ACE inhibitors in combination with DPP-4i increases BP (Jackson et al. , 2015, Marney et al. , 2010). Hence, more studies are required to confirm these effects.

\section{Modulating the expression of AT1/AT2 receptors}

AT1 causes contraction of the smooth muscle resulting in sodium and water retention leading to increased systemic vascular resistance and an increase in blood pressure. However, AT2 stimulation has opposite effects and can act as an antagonist to AT1 (Kawase et al., 2016). Hence the balance of AT1/AT2 expression determines the RAAS activity (Kaschina and Unger, 2003, Kawase et al., 2016). Some recent evidence suggests that incretins alter this relation toward more AT2 expression (Kawase et al., 2016). For example, Zhang et al. in 2015 demonstrated that liraglutide improved cardiac remodeling via altering AT1/AT2 level in cardiomyocytes of hypertensive rats (Zhang et al. , 2015). Also, Bai and colleagues in 2020 demonstrated that liraglutide and linagliptin reduced AT1/AT2 ratio in the glomerular capillaries and proximal tubules of the renal cortex of rats (Bai et al. , 2020). They suggested that incretins prevented the renal fibrosis via lowering the RAAS activity by altering AT1/AT2 ratio (Bai et al., 2020). This suggests that altering the AT1/AT2 ratio could be one of the pathways by which incretins affects the activity of RAAS.

\begin{tabular}{|c|c|c|}
\hline Molecular Pathways & Effects & Ref. \\
\hline & & Baretić et \\
& & al., 2018, \\
Beraldo et \\
Direct RAAS Inhibition & Directly inhibit RAAS activity via several ways & al., 2019, \\
& & 2012, \\
& & Mima et al., \\
& & al., 2017) et \\
\hline Modulation of NHE3 & Inhibits NHE3 activity and thereby reverses & (Carraro-La \\
Activity & croix et al., \\
& RAAS action & 2009, \\
& & Crajoinas et \\
\hline
\end{tabular}




\begin{tabular}{|c|c|c|}
\hline & & $\begin{array}{c}\text { al., 2016, } \\
\text { Du } \\
\text { Cheyron et } \\
\text { al., 2003, } \\
\text { Kim et al., } \\
\text { 2013, Skov, } \\
\text { 2014, Skov } \\
\text { et al., 2013) }\end{array}$ \\
\hline $\begin{array}{c}\text { Modulation of } \\
\text { Inflammation \& Oxidative } \\
\text { stress }\end{array}$ & $\begin{array}{c}\text { Indirectly reduces RAAS activity via damping } \\
\text { upstream events as oxidative stress and } \\
\text { inflammation }\end{array}$ & $\begin{array}{l}\text { No direct } \\
\text { evidence }\end{array}$ \\
\hline $\begin{array}{l}\text { Modulation of CNS related } \\
\text { RAAS activity }\end{array}$ & $\begin{array}{c}\text { Decline RAAS activity via modulating upstream } \\
\text { pathways located in CNS such as sympathetic } \\
\text { system and NPY }\end{array}$ & $\begin{array}{c}\text { (Tonneijck } \\
\text { et al., } \\
2014, \\
\text { Wilson et } \\
\text { al., 2019, } \\
\text { Zhang et } \\
\text { al., 2019) }\end{array}$ \\
\hline Modulating AT1/AT2 Level & $\begin{array}{l}\text { Reduce AT1/AT2 ratio leading to lower Ang II } \\
\text { effects }\end{array}$ & $\begin{array}{l}\text { (Bai et al., } \\
\text { 2020, } \\
\text { Zhang et } \\
\text { al., 2015) }\end{array}$ \\
\hline
\end{tabular}

Table 2; Possible molecular mechanisms by which GLP-1RA and/or DPP-4i modulate RAAS activity

\section{Clinical Evidence}

Some clinical studies have confirmed the RAAS-modulatory effects of incretins in human (Baretić et al., 2018, Gutzwiller et al. , 2004, Skov et al., 2013). For instance, Baretic et al. in 2018 found that GLP-1 infusion significantly altered RAAS activity and reduced aldosterone release in healthy subjects (Baretić et al., 2018). Also, Skove and coworkers in 2013 conducted a clinical study demonstrating GLP-1 infusion reduced Ang II secretion and related activities in healthy participants (Skov et al., 2013). Other main related clinical studies are presented in table 3 .

\begin{tabular}{|c|c|c|c|c|}
\hline Trial Number & $\begin{array}{c}\text { Population } \\
\text { of the study }\end{array}$ & Drug/dose/duration & Effects & Ref. \\
\hline
\end{tabular}




\begin{tabular}{|c|c|c|c|c|}
\hline NCT02130778 & $\begin{array}{c}14 \text { healthy } \\
\text { participants }\end{array}$ & $\begin{array}{c}\text { GLP-1 infusion/1.5 } \\
\text { pmol/kg/min/dissolved } \\
\text { in } 0.9 \% \text { saline/3h }\end{array}$ & $\begin{array}{c}\text { Decreased } \\
\text { aldosterone release }\end{array}$ & $\begin{array}{c}\text { (Baretić et } \\
\text { al., 2018) }\end{array}$ \\
\hline NCT01333163 & $\begin{array}{c}12 \text { healthy } \\
\text { young men }\end{array}$ & $\begin{array}{c}\text { GLP-1 infusion/1.25 } \\
\text { pmol/kg/min/dissolved } \\
\text { in } 0.9 \% \text { saline/2h }\end{array}$ & $\begin{array}{c}\text { Declined tubular } \\
\text { sodium reabsorption } \\
\text { and Ang II secretion }\end{array}$ & $\begin{array}{c}\text { (Skov et } \\
\text { al., 2013) }\end{array}$ \\
\hline- & $\begin{array}{c}15 \text { healthy } \\
\text { subjects and } \\
16 \text { obese men }\end{array}$ & $\begin{array}{c}\text { GLP-1 infusion/1.5 } \\
\text { pmol/kg/min/dissolved } \\
\text { in } 0.9 \% \text { saline/3h }\end{array}$ & $\begin{array}{c}\text { Increased urinary } \\
\text { sodium excretion }\end{array}$ & $\begin{array}{c}\text { (Gutzwiller } \\
\text { et al., } \\
\text { 2004) }\end{array}$ \\
\hline- & $\begin{array}{c}11 \text { males with } \\
\text { T2DM }\end{array}$ & $\begin{array}{c}\text { Liraglutide/1.2 } \mathrm{mg} / \mathrm{a} \\
\text { single dose }\end{array}$ & $\begin{array}{c}\text { Decreased Ang II } \\
\text { level }\end{array}$ & $\begin{array}{c}\text { (Skov et al. } \\
\text { 2016) }\end{array}$ \\
\hline- & $\begin{array}{c}61 \text { patients } \\
\text { with T2DM }\end{array}$ & $\begin{array}{c}\text { Sitagliptin/50mg/day/24 } \\
\text { weeks }\end{array}$ & $\begin{array}{c}\text { Potentiated BP } \\
\text { lowering effects of } \\
\text { ACE inhibitors }\end{array}$ & $\begin{array}{c}\text { (Fukui et } \\
\text { al. , 2015) }\end{array}$ \\
\hline & $\begin{array}{c}34 \text { patients } \\
\text { with } \\
\text { metabolic } \\
\text { syndrome }\end{array}$ & $\begin{array}{c}\text { Sitagliptin/100 mg/day } \\
\text { for } 5 \text { days }\end{array}$ & $\begin{array}{c}\text { Reversed maximal } \\
\text { ACE } \\
\text { inhibition-induced } \\
\text { hypotension }\end{array}$ & $\begin{array}{c}\text { (Marney et } \\
\text { al., 2010) }\end{array}$ \\
\hline
\end{tabular}

Table 3; Clinical studies on the RAS modulatory effects of GLP-1RA and DPP-4i

\section{Conclusion}

Renin-angiotensin system dysfunction is involved in the pathophysiology of various cardiovascular and renal disorders and thereby, RAS modulatory pharmacologic agents are commonly used to manage patients with these disorders. Incretins based pharmacological agents including GLP-1 receptor agonists and DPP-4 inhibitors, are commonly used in patients with type 2 diabetes but has shown to have some extra-pancreatic effects. In the current study, we conclude that incretins can potentially modulate RAS activity via at least five molecular pathways. This suggests that incretins-based medications are promising agents for managing patients with cardiovascular and renal disorders which need to be confirmed in clinical studies.

\section{Acknowledgment}

The authors are thankful to the "Research center of physiology, Semnan University of medical sciences (Semnan, Iran)" for providing technical supports. 


\section{Conflict of Interests}

The authors declare that they do not have any conflict of interest in this study. 


\section{References}

Ahren B. DPP-4 inhibitors. Best Practice \& Research Clinical Endocrinology \& Metabolism. 2007;21:517-33.

Alam MA, Chowdhury MRH, Jain P, Sagor MAT, Reza HM. DPP-4 inhibitor sitagliptin prevents inflammation and oxidative stress of heart and kidney in two kidney and one clip (2K1C) rats. Diabetology \& metabolic syndrome. 2015;7:107.

Association AD. Diagnosis and classification of diabetes mellitus. Diabetes care. 2014;37:S81-S90.

Association AD. 2. Classification and diagnosis of diabetes: standards of medical care in diabetes-2018. Diabetes Care. 2018;41:S13-S27.

Baetta R, Corsini A. Pharmacology of dipeptidyl peptidase-4 inhibitors. Drugs. 2011;71:1441-67. Baggio LL, Drucker DJ. Biology of incretins: GLP-1 and GIP. Gastroenterology. 2007;132:2131-57. Bai F, Zhang L-H, Zhang W-W, Zheng R-H, Eskew JR, Bennett J, et al. Conservation of glucagon like peptide-1 level with liraglutide and linagilptin protects the kidney against angiotensin II-induced tissue fibrosis in rats. European Journal of Pharmacology. 2020;867:172844.

Balamuthusamy S, Srinivasan L, Verma M, Adigopula S, Jalandara N, Hathiwala S, et al. Renin angiotensin system blockade and cardiovascular outcomes in patients with chronic kidney disease and proteinuria: a meta-analysis. American heart journal. 2008;155:791-805.

Baretić M, Kušec V, Pavlić-Renar I. Glucagon-like peptide-1 infusion suppresses aldosterone levels in healthy normal-weight individuals: double-blind, placebo-controlled crossover study. Diabetes Therapy. 2018;9:2315-24.

Beraldo JI, Benetti A, Borges-Júnior FA, Arruda-Junior DF, Martins FL, Jensen L, et al. Cardioprotection Conferred by Sitagliptin Is Associated with Reduced Cardiac Angiotensin II/Angiotensin-(1-7) Balance in Experimental Chronic Kidney Disease. International journal of molecular sciences. 2019;20:1940. Boulpaep EL, Boron WF, Caplan MJ, Cantley L, Igarashi P, Aronson PS, et al. Medical Physiology a Cellular and Molecular Approach. Signal Transduction. 2009;48:27.

Carraro-Lacroix LR, Malnic G, Girardi AC. Regulation of $\mathrm{Na}+\mathrm{H}+$ exchanger NHE3 by glucagon-like peptide 1 receptor agonist exendin-4 in renal proximal tubule cells. American Journal of Physiology-Renal Physiology. 2009;297:F1647-F55.

Choi MR, Cavallero CS, Fernandez BE. The renin angiotensin system in the central nervous system. 2011.

Crajoinas RO, Oricchio FT, Pessoa TD, Pacheco BP, Lessa LM, Malnic G, et al. Mechanisms mediating the diuretic and natriuretic actions of the incretin hormone glucagon-like peptide-1. American Journal of Physiology-Renal Physiology. 2011;301:F355-F63.

Crajoinas RO, Polidoro JZ, Carneiro de Morais CP, Castelo-Branco RC, Girardi AC. Angiotensin II counteracts the effects of CAMP/PKA on NHE3 activity and phosphorylation in proximal tubule cells. American Journal of Physiology-Cell Physiology. 2016;311:C768-C76.

de Faria Maraschin J. Classification of diabetes. Diabetes: Springer; 2013. p. 12-9.

Devin JK, Pretorius M, Nian H, Yu C, Billings IV FT, Brown NJ. Substance P increases sympathetic activity during combined angiotensin-converting enzyme and dipeptidyl peptidase-4 inhibition. Hypertension. 2014;63:951-7.

Ding X, Saxena NK, Lin S, Gupta N, Anania FA. Exendin-4, a glucagon-like protein-1 (GLP-1) receptor agonist, reverses hepatic steatosis in ob/ob mice. Hepatology. 2006;43:173-81.

Drucker DJ, Nauck MA. The incretin system: glucagon-like peptide-1 receptor agonists and dipeptidyl peptidase-4 inhibitors in type 2 diabetes. The Lancet. 2006;368:1696-705.

Du Cheyron D, Chalumeau C, Defontaine N, Klein C, Kellermann O, Paillard M, et al. Angiotensin II stimulates NHE3 activity by exocytic insertion of the transporter: role of PI 3-kinase. Kidney international. 2003;64:939-49.

Fountain JH, Lappin SL. Physiology, Renin Angiotensin System. StatPearls [Internet]: StatPearls Publishing; 2019.

Fukui K, Kawahito H, Wakana N, Kikai M, Terada K, Yamamoto K, et al. Dipeptidyl peptidase-4 inhibitor sitagliptin improves pancreatic $\beta$-cell function in hypertensive diabetic patients treated with 
angiotensin receptor blockers. Journal of the Renin-Angiotensin-Aldosterone System. 2015;16:1001-9.

Fyhrquist F, Saijonmaa O. Renin-angiotensin system revisited. Journal of internal medicine. 2008;264:224-36.

Girardi AC, Knauf F, Demuth H-U, Aronson PS. Role of dipeptidyl peptidase IV in regulating activity of $\mathrm{Na}+\mathrm{H}+$ exchanger isoform NHE3 in proximal tubule cells. American Journal of Physiology-Cell Physiology. 2004;287:C1238-C45.

Girardi ACC, Fukuda LE, Rossoni LV, Malnic G, Rebouças NA. Dipeptidyl peptidase IV inhibition downregulates $\mathrm{Na}+-\mathrm{H}+$ exchanger NHE3 in rat renal proximal tubule. American Journal of Physiology-Renal Physiology. 2008;294:F414-F22.

Gutzwiller J-P, Tschopp S, Bock A, Zehnder CE, Huber AR, Kreyenbuehl M, et al. Glucagon-like peptide 1 induces natriuresis in healthy subjects and in insulin-resistant obese men. The Journal of Clinical Endocrinology \& Metabolism. 2004;89:3055-61.

Husain K, Hernandez W, Ansari RA, Ferder L. Inflammation, oxidative stress and renin angiotensin system in atherosclerosis. World journal of biological chemistry. 2015;6:209.

Islam M. Insulinotropic Effect of Herbal Drugs for Management of Diabetes Mellitus: A

Congregational Approach. Biosens J. 2016;5:2.

Jackson EK, Mi Z, Tofovic SP, Gillespie DG. Effect of dipeptidyl peptidase 4 inhibition on arterial blood pressure is context dependent. Hypertension. 2015;65:238-49.

Kaschina E, Unger T. Angiotensin AT1/AT2 receptors: regulation, signalling and function. Blood pressure. 2003;12:70-88.

Kawase H, Bando YK, Nishimura K, Aoyama M, Monji A, Murohara T. A dipeptidyl peptidase-4 inhibitor ameliorates hypertensive cardiac remodeling via angiotensin-II/sodium-proton pump exchanger-1 axis. Journal of molecular and cellular cardiology. 2016;98:37-47.

Khanna A, English SW, Wang XS, Ham K, Tumlin J, Szerlip H, et al. Angiotensin II for the treatment of vasodilatory shock. New England Journal of Medicine. 2017;377:419-30.

Kim M, Platt MJ, Shibasaki T, Quaggin SE, Backx PH, Seino S, et al. GLP-1 receptor activation and Epac2 link atrial natriuretic peptide secretion to control of blood pressure. Nature medicine.

2013;19:567.

Koibuchi N, Hasegawa Y, Katayama T, Toyama K, Uekawa K, Sueta D, et al. DPP-4 inhibitor linagliptin ameliorates cardiovascular injury in salt-sensitive hypertensive rats independently of blood glucose and blood pressure. Cardiovascular diabetology. 2014;13:157.

Koliaki C, Doupis J. Incretin-based therapy: a powerful and promising weapon in the treatment of type 2 diabetes mellitus. Diabetes Therapy. 2011;2:101-21.

Kong AP, Yang X, So W-Y, Luk A, Ma RC, Ozaki R, et al. Additive effects of blood glucose lowering drugs, statins and renin-angiotensin system blockers on all-site cancer risk in patients with type 2 diabetes. BMC medicine. 2014;12:76.

Li P-C, Liu L-F, Jou M-J, Wang H-K. The GLP-1 receptor agonists exendin-4 and liraglutide alleviate oxidative stress and cognitive and micturition deficits induced by middle cerebral artery occlusion in diabetic mice. BMC neuroscience. 2016;17:37.

Lovshin JA, Drucker DJ. Incretin-based therapies for type 2 diabetes mellitus. Nature Reviews Endocrinology. 2009;5:262.

Lovshin JA, Zinman B. Blood pressure-lowering effects of incretin-based diabetes therapies. Canadian journal of diabetes. 2014;38:364-71.

Marney A, Kunchakarra S, Byrne L, Brown NJ. Interactive hemodynamic effects of dipeptidyl peptidase-IV inhibition and angiotensin-converting enzyme inhibition in humans. Hypertension. 2010;56:728-33.

McCormick SD, Bradshaw D. Hormonal control of salt and water balance in vertebrates. General and comparative endocrinology. 2006;147:3-8.

Meier JJ. GLP-1 receptor agonists for individualized treatment of type 2 diabetes mellitus. Nature Reviews Endocrinology. 2012;8:728. 
Messaoudi S, Azibani F, Delcayre C, Jaisser F. Aldosterone, mineralocorticoid receptor, and heart failure. Molecular and cellular endocrinology. 2012;350:266-72.

Mima A, Hiraoka-Yamomoto J, Li Q, Kitada M, Li C, Geraldes P, et al. Protective effects of GLP-1 on glomerular endothelium and its inhibition by PKC $\beta$ activation in diabetes. Diabetes. 2012;61:2967-79. Molitch ME, Adler Al, Flyvbjerg A, Nelson RG, So W-Y, Wanner C, et al. Diabetic kidney disease: a clinical update from Kidney Disease: Improving Global Outcomes. Kidney international.

2015;87:20-30.

Muskiet MH, Smits MM, Morsink LM, Diamant M. The gut-renal axis: do incretin-based agents confer renoprotection in diabetes? Nature Reviews Nephrology. 2014;10:88.

Nakagawa P, Gomez J, Grobe JL, Sigmund CD. The Renin-Angiotensin System in the Central Nervous System and Its Role in Blood Pressure Regulation. Current Hypertension Reports. 2020;22:1-10. Nangaku M, Fujita T. Activation of the renin-angiotensin system and chronic hypoxia of the kidney. Hypertension Research. 2008;31:175-84.

O’Neal KS, Johnson JL, Panak RL. Recognizing and appropriately treating latent autoimmune diabetes in adults. Diabetes Spectrum. 2016;29:249-52.

Okuyama S, Sakagawa T, Chaki S, Imagawa Y, Ichiki T, Inagami T. Anxiety-like behavior in mice lacking the angiotensin II type-2 receptor. Brain research. 1999;821:150-9.

Parving H-H, Brenner BM, McMurray JJ, De Zeeuw D, Haffner SM, Solomon SD, et al. Cardiorenal end points in a trial of aliskiren for type 2 diabetes. New England Journal of Medicine. 2012;367:2204-13. Pyke C, Heller RS, Kirk RK, Ørskov C, Reedtz-Runge S, Kaastrup P, et al. GLP-1 receptor localization in monkey and human tissue: novel distribution revealed with extensively validated monoclonal antibody. Endocrinology. 2014;155:1280-90.

Riquier-Brison AD, Leong PK, Pihakaski-Maunsbach K, McDonough AA. Angiotensin II stimulates trafficking of NHE3, NaPi2, and associated proteins into the proximal tubule microvilli. American journal of physiology-renal physiology. 2010;298:F177-F86.

Schmieder RE, Hilgers KF, Schlaich MP, Schmidt BM. Renin-angiotensin system and cardiovascular risk. The Lancet. 2007;369:1208-19.

Scott KA, Moran TH. The GLP-1 agonist exendin-4 reduces food intake in nonhuman primates through changes in meal size. American Journal of Physiology-Regulatory, Integrative and Comparative Physiology. 2007;293:R983-R7.

Sedman T, Heinla K, Vasar E, Volke V. Liraglutide treatment may affect renin and aldosterone release. Hormone and Metabolic Research. 2017;49:5-9.

Siragy HM, Carey RM. Role of the intrarenal renin-angiotensin-aldosterone system in chronic kidney disease. American journal of nephrology. 2010;31:541-50.

Skov J. Effects of GLP-1 in the kidney. Reviews in Endocrine and Metabolic Disorders.

2014;15:197-207.

Skov J, Dejgaard A, Frøkiær J, Holst JJ, Jonassen T, Rittig S, et al. Glucagon-like peptide-1 (GLP-1): effect on kidney hemodynamics and renin-angiotensin-aldosterone system in healthy men. The Journal of Clinical Endocrinology \& Metabolism. 2013;98:E664-E71.

Skov J, Pedersen M, Holst JJ, Madsen B, Gøtze JP, Rittig S, et al. Short-term effects of liraglutide on kidney function and vasoactive hormones in type 2 diabetes: a randomized clinical trial. Diabetes, Obesity and Metabolism. 2016;18:581-9.

Tamura K, Yamaji T, Yamada T, Ohsawa M, Wakui H. An interesting cross-talk between the glucagon-like peptide-1 receptor axis and angiotensin receptor pathway for modulation of renal sodium handling in obesity. Hypertension Research. 2018;41:784-6.

Thomas MC. The potential and pitfalls of GLP-1 receptor agonists for renal protection in type 2 diabetes. Diabetes \& metabolism. 2017;43:2S20-2S7.

Tonneijck L, Muskiet M, Smits MM, van Raalte DH, Diamant M. Combining incretin-based drugs and RAAS inhibitors: More cons than pros? Lancet Diabetes Endocrinol. 2014;2:684-5.

Touyz R. Reactive oxygen species and angiotensin II signaling in vascular cells: implications in cardiovascular disease. Brazilian Journal of Medical and Biological Research. 2004;37:1263-73. 
Tsuda K. Renin-angiotensin system and sympathetic neurotransmitter release in the central nervous system of hypertension. International journal of hypertension. 2012;2012.

Urushihara M, Kagami S. Role of the intrarenal renin-angiotensin system in the progression of renal disease. Pediatric nephrology. 2017;32:1471-9.

Ussher JR, Drucker DJ. Cardiovascular actions of incretin-based therapies. Circulation research.

2014;114:1788-803.

VAZIRI N. Causal link between oxidative stress, inflammation, and hypertension. 2008.

Virdis A, Duranti E, Taddei S. Oxidative stress and vascular damage in hypertension: role of angiotensin II. International journal of hypertension. 2011;2011.

Von Bohlen und Halbach O, Albrecht D. The CNS renin-angiotensin system. Cell \& Tissue Research. 2006;326.

Wilson JR, Kerman SJ, Hubers SA, Yu C, Nian H, Grouzmann E, et al. Dipeptidyl Peptidase 4 Inhibition Increases Postprandial Norepinephrine via Substance P (NK1 Receptor) During RAAS Inhibition. Journal of the Endocrine Society. 2019;3:1784-98.

Wootten D, Simms J, Koole C, Woodman OL, Summers RJ, Christopoulos A, et al. Modulation of the glucagon-like peptide-1 receptor signaling by naturally occurring and synthetic flavonoids. Journal of Pharmacology and Experimental Therapeutics. 2011;336:540-50.

Yaribeygi $\mathrm{H}$, Maleki M, Sathyapalan T, Jamialahmadi T, Sahebkar A. Anti-inflammatory potentials of incretin-based therapies used in the management of diabetes. Life Sciences. 2020;241:117152.

Yip KP, Tse CM. Modulation of $\mathrm{N} \mathrm{a}+/ \mathrm{H}+$ exchanger 3 trafficking and activity in rat proximal tubule. Acta Physiologica. 2014;210:458-9.

Zhang J, Chen Q, Zhong J, Liu C, Zheng B, Gong Q. DPP-4 Inhibitors as Potential Candidates for Anti-hypersensitive Therapy: Improving Vascular Inflammation and Assisting the Action of Traditional Antihypertensive Drugs. Frontiers in immunology. 2019;10:1050.

Zhang L-H, Pang X-F, Bai F, Wang N-P, Shah AI, McKallip RJ, et al. Preservation of glucagon-like peptide-1 level attenuates angiotensin II-induced tissue fibrosis by altering AT 1/AT 2 receptor expression and angiotensin-converting enzyme 2 activity in rat heart. Cardiovascular drugs and therapy. 2015;29:243-55. 